\title{
Experimental Investigation on Aerodynamic Characteristics for 3D Bluff Bodies: Pentagon, T, C and L-Shape Buildings
}

\author{
Vigneshwaran RAJENDRAN*, Prabavathy SHANMUGASUNDARAM
}

\begin{abstract}
Tall buildings are mostly sensitive to wind loads and the effect of wind varies in accordance with the location, shape and height of the building. It is of utmost importance to have an aerodynamically modified building in order to reduce the wind loads on tall buildings. For the present study, a sequence of wind tunnel tests was carried out for the different building of various forms such as Pentagon, T, C and L. This paper focuses on finding the aerodynamic coefficient which includes drag, lift and torsional moment coefficients. The wind tunnel is operated at a wind velocity of $10 \mathrm{~m} / \mathrm{s}$ and the building models are tested for different wind angles $0^{\circ}, 45^{\circ}, 90^{\circ}, 135^{\circ}$ and $180^{\circ}$. From the test results, it is concluded that pentagon plan shape building performs better than other shapes against aerodynamics forces.
\end{abstract}

Keywords: aerodynamic coefficient; Building Models; Drag and Lift coefficient; Tall building; Wind load

\section{INTRODUCTION}

Super-tall buildings are fast emerging in many developed and developing countries. These buildings are subject to high wind loads. It is necessary to reduce the wind loads acting on the building and to improve the comfort of the occupancies inside the buildings. Many previous researchers have worked on building aerodynamic modification such as chamfered corner in buildings plan, shapes, elevation to reduce the wind force, wind noise in the buildings, etc. Investigating of drag and lift around a 3D bluff body [3] in the shape of vehicles is done using Computational Fluid Dynamics (CFD) and validated with wind tunnel testing. Drag and lift coefficients depend on the shape of the body. The determination and comparison of wind and earthquake of Reinforced Concrete (RC) response is studied for tall towers such as minarets [31]. Consequently, the study of aerodynamic coefficients $[2,4]$ and flow characteristics around a triangular-shaped tall building using CFD simulations to assess the aerodynamic coefficients is made for seven different building models such as helical, tapered, setback, recessed, corners, chamfered corner, sharp corner, in order to find the drag and lift coefficients $[30,9]$. The result emphasizes that minimum drag has occurred in a chamfered corner of drag coefficient 0.6 , followed by a helical, tapered, setback and recessed corners of drag coefficient $0.62,0.79,0.9$ and 1 respectively. In further researches $[13,33]$ the wind flows around a cylinder with a low aspect ratio of 1:4. The simulation is carried at $45^{\circ}$ wind angle with varying the Reynolds number by 10,50 , 100, 200 and 300 and extended the studies by using Reynolds number 50 for different wind angles such as $0^{\circ}$, $15^{\circ}, 30^{\circ}, 45^{\circ}, 60^{\circ}, 75^{\circ}$ and $90^{\circ}$ respectively. With an aim in investigating the mean drag, lift and torsional moment coefficient for rectangular high rise building under different wind angles $0^{\circ}, 5^{\circ}, 10^{\circ}, 15^{\circ}, 25^{\circ}, 33.5^{\circ}, 45^{\circ}, 56.5^{\circ}$, $60^{\circ}, 75^{\circ}, 87.5^{\circ}$ and $90^{\circ}$ under uniform flow is tested in wind tunnel. The result understands that the change in wind angle influences the drag coefficient and maximum drag is found in the building with larger frontal area. Aerodynamic coefficient depends on the building shape and with an eye on building aerodynamics, previous researcher [18] worked on building with setbacks and carried out a study using wind tunnel and CFD for a wind angle of $0^{\circ}$ and $90^{\circ}$ respectively. In this sphere, authors [8] investigated the aerodynamic coefficients by varying the terrain category as suburban, open and uniform terrain for $0^{\circ}$ and $90^{\circ}$ wind angles using wind tunnel. The investigation resulted in changes in terrain category and had a direct influence on aerodynamic coefficients such as drag and lift forces. The experimental and numerical simulations [5] are tested for an E plan shape building in asymmetry with both plan axes. The wind angles vary from $0^{\circ}$ to $330^{\circ}$ by varying the wind direction. The results prove that modifying the building shapes results in change in pressure coefficient on various faces of the building. Such type of modification helps in reducing the wind loads on tall buildings. Tall building is subjected to along wind force, across wind force and torsional moments. The investigation of across wind forces is done for fifteen typical tall buildings [23, 19]. The test is conducted experimentally using high frequency force balancing test and new formula for cross wind power spectra is found and compared with the present formula. A study is made on investigating [16] the drag and lift coefficient for building by varying the side and aspect ratio. The study documents that when the side ratio increases the local drag coefficient decreases and when the aspect ratio increases the local drag increases. In exploration of the wind effect in high rise buildings, the base moment is calculated for along wind direction $C_{M x}$, across wind direction $C_{M y}$ and torsional base moment $C_{M z}[10,22]$. The investigation shows that the buildings having number of sides can be able to reduce the base moment. From the result of the previous researchers, it is found that the value of drag and lift depends on the shape of the building, wind angles, Reynolds number (Re), density of the fluid and terrain category.

For the design of tall building wind loads are the major design paramters to be considered, but most of the wind engineering codes such as IS:875 (Part 3):2015, AS/NZS 1170-2 2011, ASCE 7-10-2010; etc, lack in presenting the aerodynamic coefficient and moment coefficient for unconventional plan shape building. This paper investigates the aerodynamic coefficient, which includes drag and lift coefficents and moment coeffcient for the pentagon, $\mathrm{L}, \mathrm{T}$, and $\mathrm{C}$ plan shape tall building for different wind angles. 


\section{EXPERIMENTAL SETUP}

The experiment is conducted in a subsonic wind tunnel available in Kumaraguru Engineering College, Coimbatore. The length of the tunnel is $40 \mathrm{~m}$ and the test section of size $600 \mathrm{~mm} \times 600 \mathrm{~mm}$. Blockage ratio for this test is more than $5 \%$ and so, necessary blockage correction is performed in order to reduce the overestimated flow. Fig. 1 and Fig. 2 show the pictorial and schematic representation of the wind tunnel. The building models and wind speed are scaled in the ratio 1:300, 1:5 respectively. The fabrication of the building models is done using a transparent acrylic sheet.

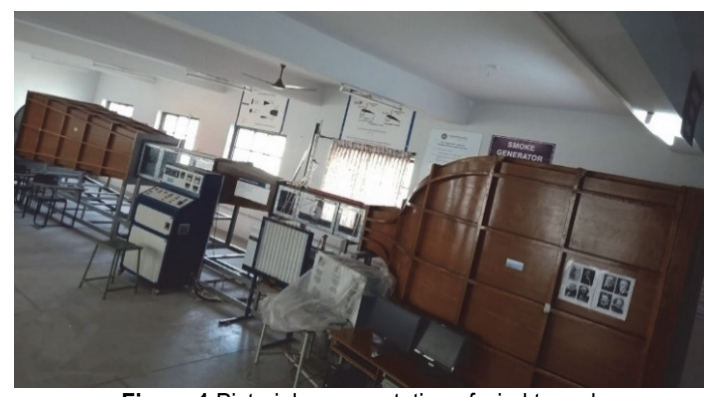

Figure 1 Pictorial representation of wind tunnel

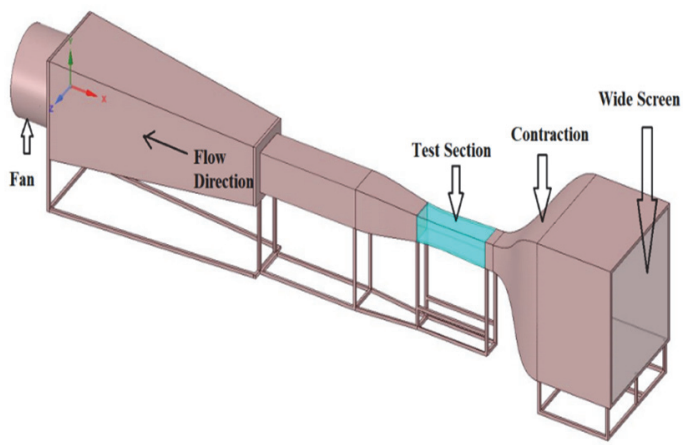

Figure 2 Schematic representation of wind tunnel
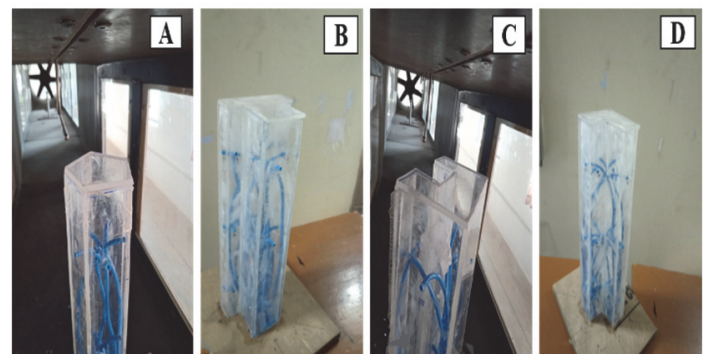

Figure 3 Fabricated building models (a) Pentagon (b) T-shape (c) C-shape (d) L-shape

Fig. 3 shows the fabricated building models (a) Pentagon, (b) L (c) $\mathrm{T}$ and (d) $\mathrm{C}$ plan shape. The tunnel is operated at a wind speed of $10 \mathrm{~m} / \mathrm{s}$. Pressure taps are positioned on all the faces at different levels of the building of height $50 \mathrm{~mm}, 150 \mathrm{~mm}$ and $250 \mathrm{~mm}$ from the base. Totally 24 pressure taps are made for $\mathrm{C}$ and $\mathrm{T}$ shape building model, 18 and 15 pressure taps are made for $\mathrm{L}$ and pentagon shape building. The building models are fitted to a thick plywood in order to hold the building models in correct position. Fig. 4 shows the location of pressure taps for different building models. Fig. 5 shows the coordinate system for pentagon, T, C and L plan shape building.
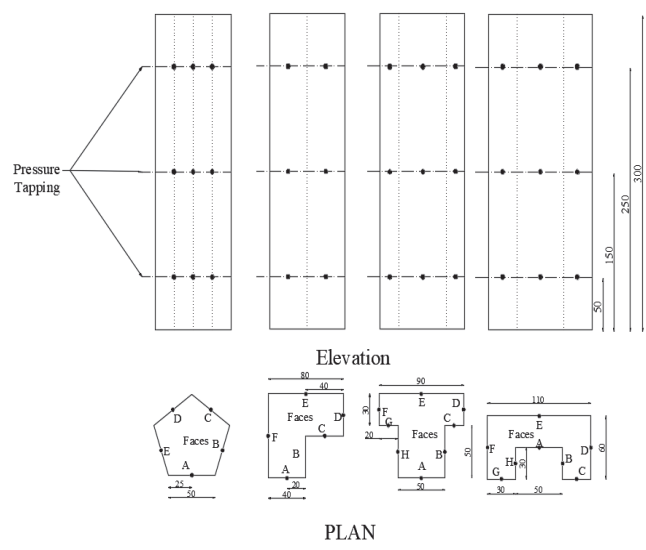

Figure 4 The figure shows the location of pressure traps for Pentagon, L, T and $\mathrm{C}$ plan shape building (All dimensions are in $\mathrm{mm}$ )

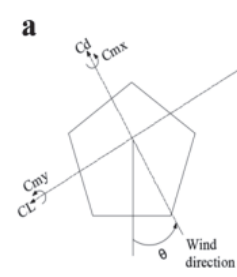

b
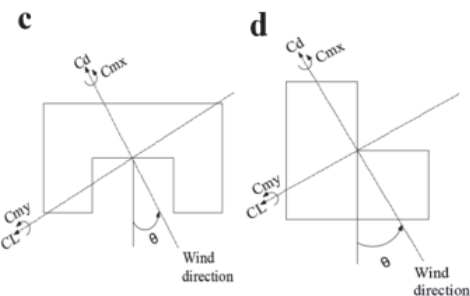

Figure 5 Coordinate system (a) Pentagon shape building (b) T shape building (c) $C$ shape building (d) $L$ shape building

\subsection{Wind Flow Setup}

The wind flow near the boundary layer is shown in Fig. 6. The maximum wind speed obtained in the upstream side of the test section is $10 \mathrm{~m} / \mathrm{s}$. Proper simulation of wind characteristic is made in order to replicate the corresponding prototype condition. The experiment flow is simulated similar to terrain category II as per IS 875 (Part$3)$. The power-law index $(\alpha)$ for tunnel is 0.133 .

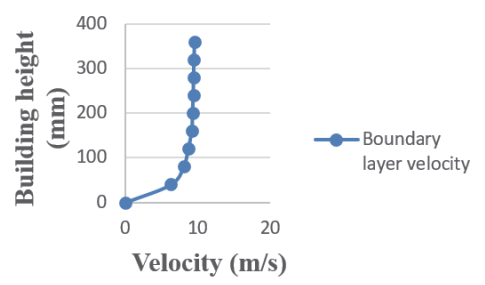

Figure 6 Coordinate system (a) Pentagon shape building (b) T shape building (c) $C$ shape building (d) $L$ shape building

\section{PARAMETRIC STUDY}

The actual building height is 90 meters and 1:300 scale is used for the model. The following building shapes are considered in the study of pentagon, T, C and L plan shape. The buildings are tested for different wind angles $0^{\circ}, 45^{\circ}$, 
$90^{\circ}, 135^{\circ}$ and $180^{\circ}$. Fig. 7 shows the dimension of the building models for pentagon, T, C and L plan shapes.

\section{RESULTS AND DISCUSSION}

A Wind tunnel test is conducted for tall buildings of shapes pentagon, $\mathrm{L}, \mathrm{T}$ and $\mathrm{C}$ for wind angles $0^{\circ}, 45^{\circ}, 90^{\circ}$, $135^{\circ}$ and $180^{\circ}$. The wind tunnel is operated at wind velocity of $10 \mathrm{~m} / \mathrm{s}$ and the pressure measurements are calculated using the Eq. (1). [16]

$$
C_{p, \text { mean }}=\frac{p-p_{0}}{\frac{1}{2} \rho U_{H}^{2}}
$$

where $p$ is the pressure from the point, $p_{0}$ is the pressure at reference height, $\rho$ is the density of the air as $1.225 \mathrm{~kg} / \mathrm{m}^{3}$. $U_{H}$ is the mean wind velocity at the height $H$.
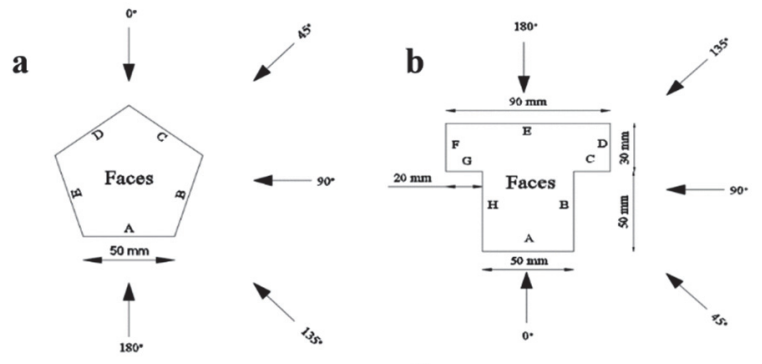

C

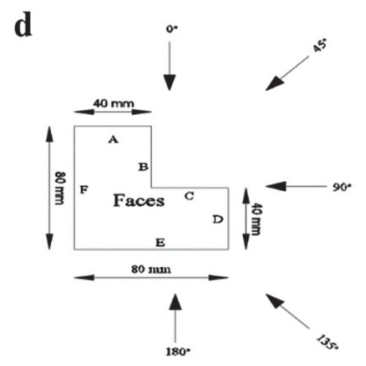

Figure 7 Dimension of tall buildings of shapes (a) Pentagon (b) T-shape (c) Cshape (d) L-shape

Table 1 Blockage correction (n) for different building shapes and wind angles

\begin{tabular}{|c|c|c|c|}
\hline Building shapes & Wind angles & $\begin{array}{c}\text { Blockage value / } \\
\%\end{array}$ & $\begin{array}{c}\text { Blockage } \\
\text { correction } n\end{array}$ \\
\hline \multirow[t]{5}{*}{ Pentagon } & $0^{\circ}$ & $6.7 \%$ & 1.017 \\
\hline & $45^{\circ}$ & $6.6 \%$ & 1.016 \\
\hline & $90^{\circ}$ & $6.4 \%$ & 1.014 \\
\hline & $135^{\circ}$ & $6.6 \%$ & 1.016 \\
\hline & $180^{\circ}$ & $6.7 \%$ & 1.017 \\
\hline \multirow[t]{5}{*}{ T plan shape } & $0^{\circ}$ & $7.5 \%$ & 1.025 \\
\hline & $45^{\circ}$ & $8.8 \%$ & 1.038 \\
\hline & $90^{\circ}$ & $6.6 \%$ & 1.016 \\
\hline & $135^{\circ}$ & $8.8 \%$ & 1.038 \\
\hline & $180^{\circ}$ & $7.5 \%$ & 1.025 \\
\hline \multirow[t]{5}{*}{ C plan shape } & $0^{\circ}$ & $7.5 \%$ & 1.025 \\
\hline & $45^{\circ}$ & $7.9 \%$ & 1.029 \\
\hline & $90^{\circ}$ & $3.7 \%$ & $\begin{array}{l}\text { No correction } \\
\text { required }\end{array}$ \\
\hline & $135^{\circ}$ & $7.9 \%$ & 1.029 \\
\hline & $180^{\circ}$ & $7.5 \%$ & 1.025 \\
\hline \multirow[t]{5}{*}{ L plan shape } & $0^{\circ}$ & $6.6 \%$ & 1.066 \\
\hline & $45^{\circ}$ & $9.4 \%$ & 1.044 \\
\hline & $90^{\circ}$ & $6.6 \%$ & 1.016 \\
\hline & $135^{\circ}$ & $7.0 \%$ & 1.02 \\
\hline & $180^{\circ}$ & $6.6 \%$ & 1.06 \\
\hline
\end{tabular}

Maskell in the year 1958 introduced the blockage correction [26] in order to reduce the overestimated flow. Since the value of the blockage ratio is more than $5 \%$ for this study, the necessary correction is made using the Eq. (2), where $\mathrm{n}$ is the blockage correction factor.

$C_{p, \text { Corrected }}=\frac{C_{p, m}}{n}+\frac{(n-1)}{n}$

Pressure Coefficient $\left(C_{p}\right)$ is investigated for various faces for the building models, for different wind angles $0^{\circ}$, $45^{\circ}, 90^{\circ}, 135^{\circ}$ and $180^{\circ}$ and the calculated $C_{p}$ value is used in investigating the drag and lift coefficients.

\subsection{Effect of Reynolds Number}

Reynolds number $(R e)$ is a dimensionless quantity which acts as an important parameter in predicting the fluid flow. Reynolds number is the ratio of inertia force to viscous force. Reynolds number is calculated using the Eq. (3).

$R e=\frac{U D}{v}$

where, $D$ is the characteristic dimension, $v$ is the kinematic viscosity. Usually, the flow pattern, separation of flow, reattachments, formation of vortex depend upon the $R e$ [25]. Generally, $R e$ varies with respect to the building dimensions, shapes, wind angle and wind velocity. $R e$ depends upon the aspect ratio, orientation, of the building. Authors [12, 27, 29] studied the flow characteristics around a triangular prism with low $R e$ and rectangular cylinder with aspect ratio of 1:5 followed by high $R e$ number over rectangular cylinder [1]. Tab. 2 shows the $R e$ for tall building of shapes pentagon, $\mathrm{T}, \mathrm{C}$ and $\mathrm{L}$ plan with different wind angles. The drag and lift coefficients depend on the $R e$ and it varies for different building shapes and wind angles.

Table 2 Reynolds number for different plan shape buildings with different wind

\begin{tabular}{|c|c|c|c|c|c|}
\multicolumn{7}{|c|}{ angles } \\
\hline Building Shape & $0^{\circ}$ & $45^{\circ}$ & $90^{\circ}$ & $135^{\circ}$ & $180^{\circ}$ \\
\hline Pentagon plan & $7.67 \times$ & $7.97 \times$ & $8.07 \times$ & $7.97 \times$ & $7.67 \times$ \\
shape & $10^{7}$ & $10^{7}$ & $10^{7}$ & $10^{7}$ & $10^{7}$ \\
\hline T plan shape & $7.98 \times$ & $1.06 \times$ & $8.98 \times$ & $1.06 \times$ & $7.98 \times$ \\
& $10^{7}$ & $10^{8}$ & $10^{7}$ & $10^{8}$ & $10^{7}$ \\
\hline C plan shape & $4.49 \times$ & $9.53 \times$ & $8.97 \times$ & $9.53 \times$ & $4.49 \times$ \\
& $10^{7}$ & $10^{7}$ & $10^{7}$ & $10^{7}$ & $10^{7}$ \\
\hline L plan shape & $7.98 \times$ & $8.47 \times$ & $7.98 \times$ & $1.13 \times$ & $7.98 \times$ \\
& $10^{7}$ & $10^{7}$ & $10^{7}$ & $10^{8}$ & $10^{7}$ \\
\hline
\end{tabular}

\subsection{Drag Coefficient for Different Building Shapes}

The along wind force leads to the creation of drag force and the measurements are made on the building model at different heights $(h / 6, h / 2$ and $4.15 h / 5)$ in buildings. Drag is a dimensionless number [7, 33]. Eq. (4) shows the calculation of the drag coefficient.

$C_{D \text {,mean }}=\frac{F_{D}}{\frac{1}{2} \rho V^{2} A}$ 
where $C_{\text {DMean }}$ is the drag force coefficient, $F_{D}$ is the drag force, $\rho$ is the density of air, $V$ is the velocity of wind and $A$ is the cross-sectional area. The drag force is created by along wind force mainly due to the pressure distribution on the windward and leeward face of the buildings. The procedure for the calculation of maximum cross-sectional area $(A)$ is done as per the recommendation given by Flachsbarto (1932) [11]. From this study of pentagon shape building experiences, a maximum drag coefficient of 1.349 at $90^{\circ}$ wind angle was followed by other wind angles $0^{\circ}$, $180^{\circ}, 45^{\circ}$ and $135^{\circ}$ of drag coefficients $1.209,0.926,0.922$, 0.912 respectively. The lower value of drag coefficients has occurred at $135^{\circ}, 45^{\circ}$ and $180^{\circ}$ wind angles. The drag coefficient depends on the pressure coefficient and $R e$ on the building [6] when the building experiences a large pressure coefficient, the value of drag will be maximum and at the same time, minimum drag is experienced when the building experiences less pressure coefficient. Since lower drag leads in the creation of lower aerodynamic tension, drag force depends on the pressure coefficient on the building surface. With regard to $\mathrm{T}$ shape tall building maximum drag has occurred at $45^{\circ}$ wind angle of drag coefficient 2.371 , further by other wind angles $0^{\circ}, 135^{\circ}$, $180^{\circ}$ and $90^{\circ}$, with a drag coefficient of value 2.0367 , $1.9014,1.679$ and 1.5603 respectively. The minimum drag has occurred at $90^{\circ}$ wind angle of drag coefficient 1.5603 , whereas for $\mathrm{C}$ - plan shape tall building maximum drag coefficient has occurred at $0^{\circ}$ wind angle of value 2.593 . Subsequently, the drag coefficient is obtained for other wind angles $135^{\circ}, 180^{\circ}, 45^{\circ}$ and $90^{\circ}$ of drag coefficients of values $2.29,2.0,1.805$ and 1.16 respectively. With respect to $\mathrm{L}$ - plan shape tall building, maximum drag has occurred at $0^{\circ}$ and $45^{\circ}$ wind angle of value 1.4 , further by other wind angles $135^{\circ}, 180^{\circ}$ and $90^{\circ}$ of drag coefficient $1.36,1.05$ and 1.18 respectively. Fig. 8 shows the drag Coefficients $\left(C_{d}\right)$ for different shape building (a) pentagon plan shape (b) $\mathrm{T}$ - plan shape (c) C - plan shape (d) L - plan shape. Graphs of drag, lift and moment coefficient follow a similar pattern as that of the previous researchers [17, 32]; the drag coefficient changes at different levels in building height.

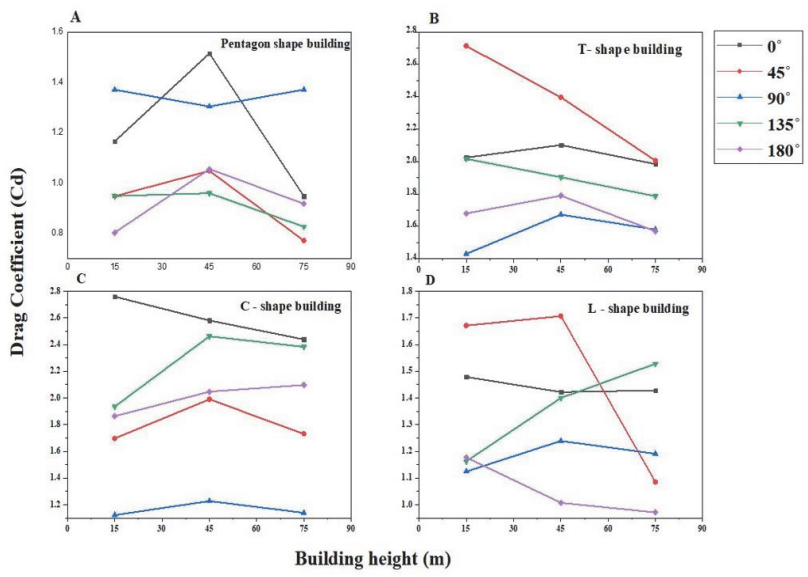

Figure 8 Drag Coefficient for different plan shape building (a) pentagon plan shape (b) T - plan shape (C) C - plan shape (d) L - plan shape

\subsection{Drag Coefficient for Different Wind Angles}

In the current analysis of drag coefficient, pentagon shape tall building observes minimum drag coefficient for the wind angles $0^{\circ}, 45^{\circ}, 135^{\circ}$ and $180^{\circ}$ when compared with $\mathrm{L}$ and $\mathrm{T}$. For $90^{\circ}$ wind angle, $\mathrm{C}$ - plan shape building attains minimum drag coefficient of 1.16218 . With regard to $0^{\circ}$ wind angle, maximum drag had occurred at $\mathrm{C}$ - plan shape tall building followed by $\mathrm{T}, \mathrm{L}$ and Pentagon plan shape buildings. Since pentagon plan shape has minimum drag coefficient, the results are discussed by comparing the pentagon shape building model with other different shape buildings.

For $0^{\circ}$ wind angle experiences a greater drag force than pentagon by $26 \%, 73 \%$ and $136.75 \%$ for $\mathrm{L}$, T and C plan shape tall building. At this wind angle, building model height $\mathrm{h} / 6$ from the base experiences a greater drag force than pentagon by $26 \%, 73 \%$ and $136.75 \%$ for $\mathrm{L}, \mathrm{T}$ and $\mathrm{C}$ plan shape tall building. With regard to building model height $\mathrm{h} / 2$ from the base, pentagon plan shape experiences lower drag coefficient of $6.13 \%$ than L plan shape building and greater drag coefficient of $38.79 \%, 70.42 \%$ for $\mathrm{T}$ and $\mathrm{C}$ plan shape tall buildings. Considering building model height at $4.15 \mathrm{~h} / 5$ i.e in the top position of the building it experiences greater drag force than pentagon plan shape building by $50.67 \%, 109.35 \%$ and $157.31 \%$ for L, T and C plan shape tall building. Fig. $9 \mathrm{a}$ shows the drag coefficient for $0^{\circ}$ wind angle.

For $45^{\circ}$ wind angle, maximum drag is found in $\mathrm{T}$ plan shape building followed by $\mathrm{C}, \mathrm{L}$ and Pentagon. At building height $4.15 h / 5$, greater drag coefficient is found in pentagon plan shape building and less by $76.26 \%, 186.19 \%$ and $78.94 \%$ for $\mathrm{L}, \mathrm{T}$ and $\mathrm{C}$ plan shape building. With regard to the mid-height of the building model, i.e., h/2, pentagon plan shape buildings experience, greater drag than other building shapes by $62.81 \%$ for L plan shape building, $128.59 \%$ for T plan shape building and $89.8 \%$ for $\mathrm{C}$ plan shape buildings. Considering building model height at $4.15 h / 5$, for $45^{\circ}$ wind angle experiences greater drag than pentagon plan shape building by $40.6 \%, 159.9 \%$ and $124.34 \%$ for L, T and C plan shape building. Fig. $9 \mathrm{~b}$ shows the drag coefficient for $45^{\circ}$ wind angles.

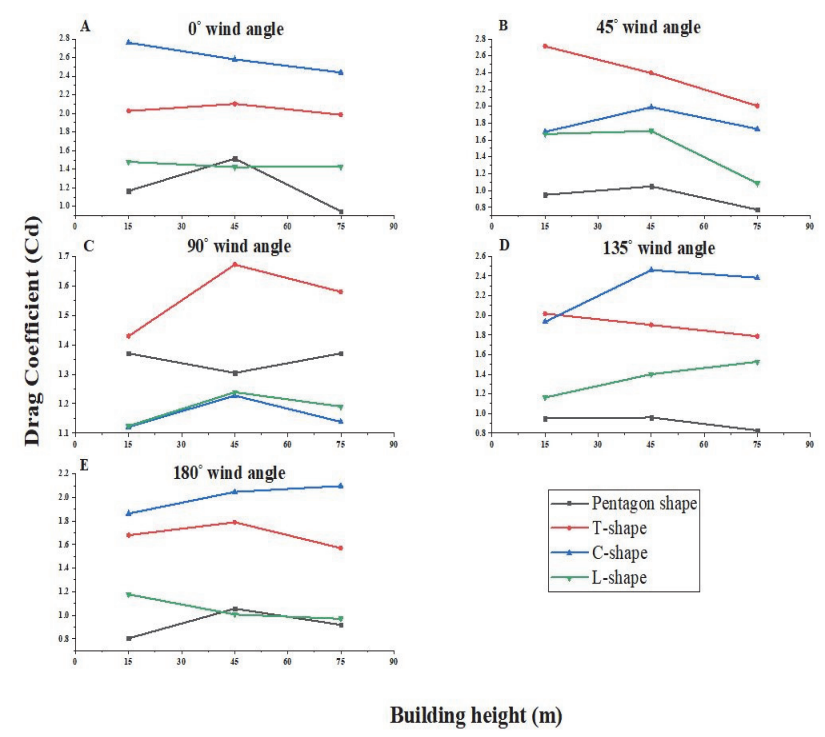

Figure 9 Drag Coefficient for different wind angles (a) $0^{\circ}$ (b) $45^{\circ}$ (C) $90^{\circ}$ (d) $135^{\circ}$ (e) $180^{\circ}$ wind angle

For $90^{\circ}$ wind angle, maximum drag is experienced in $\mathrm{T}$-shape building followed by pentagon, $\mathrm{L}$ and $\mathrm{C}$ plan 
shape tall building. At building model height $\mathrm{h} / 6$ from base, $90^{\circ}$ wind angle experiences lower drag coefficient for $\mathrm{L}$ and $\mathrm{C}$ plan shape tall building by $17.9 \%$ and $18.2 \%$ and greater drag force by $4.28 \%$ for $\mathrm{T}$ plan shape when compared with pentagon plan shape tall building. Considering building model height at $h / 2$ from the base, at $90^{\circ}$ wind angle $\mathrm{L}$ and $\mathrm{C}$ plan shape building experiences lower drag force by $13.16 \%$ and $16.97 \%$ and greater drag force by $15.23 \%$ for $\mathrm{T}$ plan shape tall building when compared with pentagon plan. Fig. 9c shows the drag coefficient for $90^{\circ}$ wind angle.

For $135^{\circ}$ wind angle, maximum drag is found for Cshape building followed by $\mathrm{T}, \mathrm{L}$ and Pentagon. For building model height $h / 6$ from the base at $135^{\circ}$ wind angle experiences greater drag than pentagon by $22.5 \%$, $112.51 \%$ and $103.89 \%$ for $\mathrm{L}, \mathrm{T}$ and $\mathrm{C}$ plan shape tall building followed by $h / 2$ (middle position) and $4.15 h / 5$ (top position) experiences greater drag coefficient than pentagon by $45.87 \%, 84.78 \%$ for L, $98.23 \%, 115.95 \%$ for $\mathrm{T}$ and $156.23 \%, 188.18 \mathrm{C}$ - plan shape building. Fig. 9d shows the drag coefficient for $135^{\circ}$ wind angles.

At $180^{\circ}$ wind angle, $h / 6$ from the base of the building experiences greater drag coefficient than pentagon by $46.41 \%, 108.88 \%$ and $131.69 \%$ for $\mathrm{L}, \mathrm{T}$ and $\mathrm{C}$ followed by $\mathrm{h} / 2$ (middle position) at $180^{\circ}$ wind angle experiences lower drag coefficient by $4.56 \%$ for L plan shape and greater drag coefficient about $69.53 \%$ and $93.96 \%$ for $\mathrm{T}$ and $\mathrm{C}$ plan shape tall building. At $4.15 h / 5$ (top position) at building height for $\mathrm{L}, \mathrm{T}$ and $\mathrm{C}$ experiences greater drag force than pentagon by $5.794 \%, 70.93 \%$ and $128.38 \%$. Fig. 9 e shows the drag coefficients for $180^{\circ}$ wind angles. Earlier researchers [14] investigated the drag coefficient for rectangular building for wind angles $0^{\circ}$ and $90^{\circ}$ by changing the terrain category. From the results only $3 \%$ variation in the results have been observed at lower position of the building followed by $15-40 \%$ for the other side of building height. Drag and lift depends on the formation of vortex on the $3 \mathrm{D}$ bluff bodies.

\subsection{Lift Coefficient for Different Building Shapes}

Cross-wind force leads to the formation of lift forces and lift coefficients are calculated using the relation Eq. (5), which is a non-dimensional parameter.

$$
C_{\mathrm{L}, \text { mean }}=\frac{F_{L}}{\frac{1}{2} \rho V^{2} A}
$$

where $C_{L}$ means lift coefficient, $F_{L}$ is the Lift force, $\rho$ is the density of air, $V$ is the velocity of wind, $A$ is the crosssectional area.

The author [28] investigated the lift coefficient for 3D rectangular tall building. Strength and frequency of the structure mainly depend upon the lift forces. In the current research, pentagon plan shape building experiences a maximum lift at $45^{\circ}$ wind angle followed by $135^{\circ}, 180^{\circ}$, $90^{\circ}, 0^{\circ}$ and the drag coefficients obtained are $0.67,0.98$, $0.22,0.85,0.02$ respectively.

Tall buildings with a $\mathrm{T}$ plan shape have the highest drag coefficient at $135^{\circ}$ wind angle, followed by $90^{\circ}, 45^{\circ}$, $180^{\circ}$, and $0^{\circ}$ wind angle of lift coefficient of value 0.98 ,
$0.85,0.67,0.22,0.02$ respectively. When it comes to $\mathrm{C}$ plan shape tall building, maximum drag has occurred at $135^{\circ}$ wind angle followed by $90^{\circ}, 45^{\circ}, 180^{\circ}$ and $0^{\circ}$ wind angles of lift coefficients 1.51, 0.86, $0.68,0.01$ and 0.02 respectively. With respect to $\mathrm{L}$ - plan shape building, maximum lift is found at $135^{\circ}$ wind angle followed by $0^{\circ}$, $45^{\circ}, 90^{\circ}$ and $180^{\circ}$ wind angle of lift values $1.46,1.01,0.94$, $0.25,0.17$ respectively. Fig. 10 shows the lift coefficients for different plan shape buildings (a) pentagon plan shape (b) T - plan shape (C) C - plan shape and (d) L - plan shape.

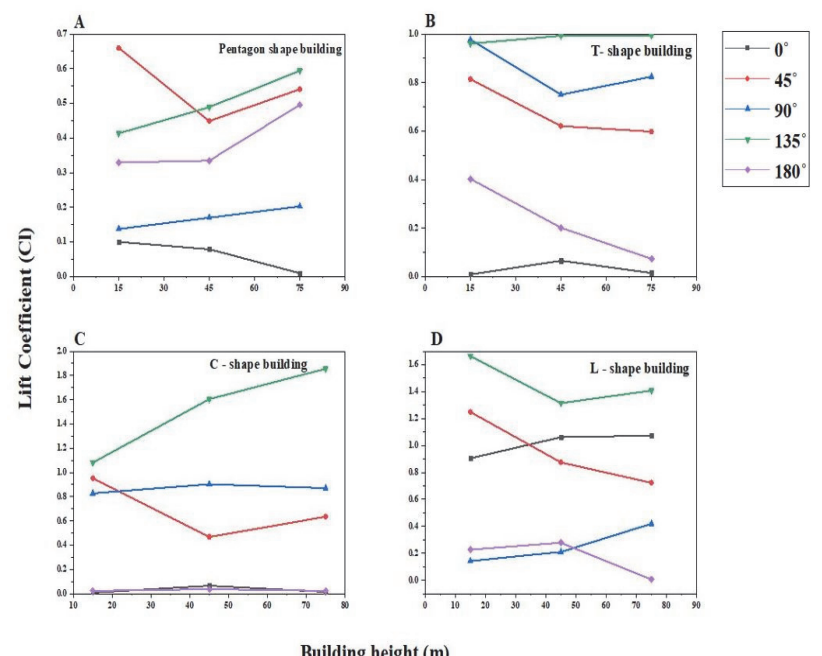

Figure 10 Lift coefficients for different plan shape building (a) pentagon plan shape (b) T - plan shape (C) C - plan shape (d) L - plan shape

\subsection{Lift Coefficient for Different Wind Angles}

Lift forces are created due to crosswind direction. From the result, it is observed that pentagon plan shape tall building experiences minimum lift coefficient when compared to other building shapes $\mathrm{C}, \mathrm{T}$ and $\mathrm{L}$. When compared with pentagon plan shape building, with the building model height of $h / 6$ from the base, L - plan shape building at $0^{\circ}$ wind angle experiences greater lift coefficient of $806.3 \%$ and lower lift coefficient for $\mathrm{T}$ and C plan shape by $91.55 \%$ and $91.54 \%$. At a building height $h / 2$, for $0^{\circ}$ wind angle pentagon plan shape building experiences greater lift coefficient by $1250.92 \%$ for L plan shape building and lower lift coefficient for $\mathrm{T}$ and $\mathrm{C}$ plan shape by $16.17 \%$ and $15.89 \%$. For the building height 4.15 $h / 5$ from the base at $0^{\circ}$ wind angle pentagon plan shape building experiences greater lift coefficient by $11353.8 \%$ for $\mathrm{L}$ plan shape building and lesser lift coefficient for $\mathrm{T}$ and $C$ plan shape by 60.57 and $62.93 \%$ respectively. $T$ and $\mathrm{C}$ plan shape tall building experiences the same lift values for $0^{\circ}$ wind angle only minor deviation is observed. Fig. 11 a shows the lift coefficient for $0^{\circ}$ wind angle.

Building model at a height of $h / 6$ from the base, at $45^{\circ}$ wind angle obtained a lift coefficient greater than pentagon plan shape tall building by $89.33 \%, 23.35 \%$ and $44.23 \%$ for L, T and C plan shape tall building. For building model at height $\mathrm{h} / 2$ from the base, at $45^{\circ}$ wind angle obtained a lift coefficient greater than pentagon plan shape tall building by $94.85 \%, 38.16 \%$ and $4.26 \%$ for $\mathrm{L}$, T and C plan shape tall building. For the building model at height 4.15 $h / 5$ from the base at $45^{\circ}$ wind angle, obtained a lift coefficient greater than pentagon plan shape tall building 
by $33.72 \%, 10.54 \%$ and $17.67 \%$ for $\mathrm{L}$, $\mathrm{T}$ and $\mathrm{C}$ plan shape tall building. Fig. $11 \mathrm{~b}$ shows the lift coefficient for $45^{\circ}$ wind angles.

With regard to $90^{\circ}$ wind angle at building height $h / 6$ from the base, it obtained a lift coefficient greater than pentagon plan shape tall building by $4.45 \%, 611.54 \%$ and $503.4 \%$ for $\mathrm{L}, \mathrm{T}$ and $\mathrm{C}$ plan shape tall building. At building height $h / 2$ from the base, towards $90^{\circ}$ wind angle obtained a lift coefficient greater than pentagon plan shape tall building by $23.93 \%, 341.39 \%$ and $431.57 \%$ for $\mathrm{L}, \mathrm{T}$ and C plan shape tall building. At building height $4.15 h / 5$ from the base, about $90^{\circ}$ wind angle pentagon plan shape building obtained a maximum drag greater than $107.25 \%$, $3016.51 \%$ and $329.28 \%$ for $\mathrm{L}, \mathrm{T}$ and $\mathrm{C}$ plan shape tall building. Fig. 11c shows the lift coefficient for $90^{\circ}$ wind angles.

For $135^{\circ}$ wind angle at building height $h / 6$ from the base obtained a lift coefficient greater than pentagon plan shape tall building by $302.78 \%, 133.38 \%$ and $161.71 \%$ for $\mathrm{L}, \mathrm{T}$ and $\mathrm{C}$ plan shape tall building. At building height $h / 2$ from the base it experiences a greater lift value than pentagon by $168.69 \%, 103.08 \%$ and $228.25 \%$ for $\mathrm{L}, \mathrm{T}$ and C plan shape tall buildings. At $4.15 h / 5$ from the base of the building model, it experiences larger lift coefficient by $137.101 \%, 67.203 \%$ and $211.313 \%$ for $\mathrm{L}, \mathrm{T}$ and $\mathrm{C}$ plan shape tall building at $135^{\circ}$ wind angles. Fig. $11 \mathrm{~d}$ shows the lift coefficient for $180^{\circ}$ wind angles.

For $180^{\circ}$ wind angle the pentagon plan shape building experiences lower lift coefficient of $30.71 \%, 92.45 \%$ when compared with $\mathrm{L}$ and $\mathrm{C}$ plan shape tall building and greater lift coefficient of about $22.21 \%$ is observed for $\mathrm{T}$ plan shape tall building, whereas for building model height 150 $\mathrm{mm}$ from the base it experiences lower lift coefficient by $16.82 \%, 39.89 \%$ and $88.98 \%$ for $\mathrm{L}, \mathrm{T}$ and $\mathrm{C}$ plan shape tall building at $180^{\circ}$ wind angles. For the building height 250 $\mathrm{mm}$ from the base it experiences lower lift coefficient than pentagon shape tall building by $98.79 \%, 85.33 \%$ and $94.98 \%$ for $\mathrm{L}, \mathrm{T}$ and $\mathrm{C}$ plan shape tall building at $180^{\circ}$ wind angle. The cross wind loading in high rise building is investigated through wind tunnel by steady suction method [7, 15]. Fig. 11e shows the lift coefficient for $180^{\circ}$ wind angles.

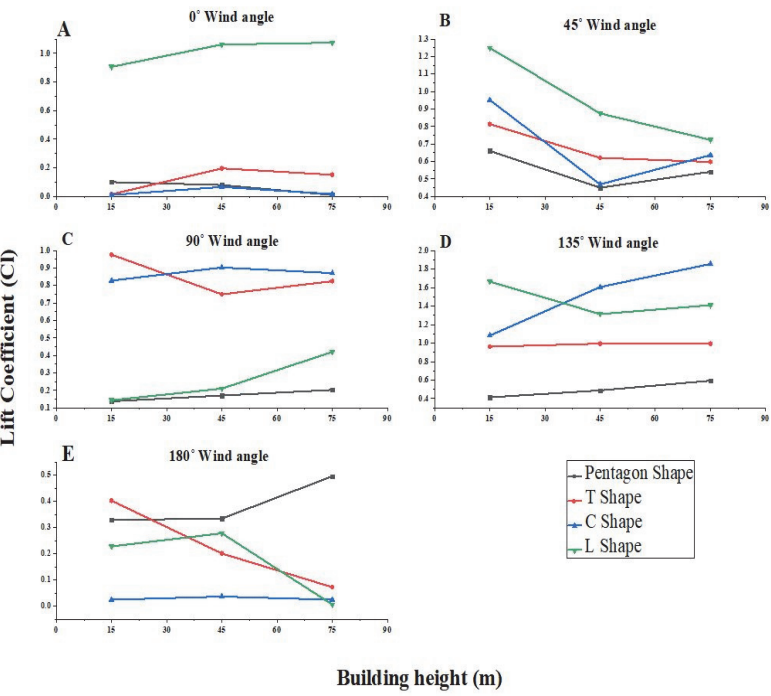

Figure $11 \mathrm{Lift}$ coefficients for different wind angles (a) $0^{\circ}$ (b) $45^{\circ}$ (C) $90^{\circ}$ (d) 135 (e) $180^{\circ}$

\subsection{Comparison between Drag and Lift Coefficient}

Drag force is formed along wind direction and lift force is formed across wind direction i.e on the side face of the building. Pentagon shape building at $0^{\circ}$ wind angle experiences a large drag when compared to lift coefficient by $109.9 \%$ followed by other wind angles of $90^{\circ}, 180^{\circ}$, $135^{\circ}, 45^{\circ}$ of $7.9 \%, 2.39 \%, 1.82 \%$ and $1.67 \%$ respectively. Fig. 12a compares the difference between drag and lift coefficients for pentagon plan shape building.

With respect to $\mathrm{T}$-shape building at $0^{\circ}$ wind angle experiences a larger drag when compared to lift coefficient by $101.85 \%$ followed by other wind angles $180^{\circ}, 45^{\circ}, 135^{\circ}$ and $90^{\circ}$ of $7.42 \%, 3.53 \%, 1.93 \%$ and $1.83 \%$ respectively. Fig. 12b compares the drag and lift coefficient for $\mathrm{T}$ - plan shape building.

With regard to $\mathrm{C}$ - plan shape building experiences maximum drag to lift ratio for $180^{\circ}$ wind angle by $200 \%$, followed by other wind angles of $0^{\circ}, 45^{\circ}, 135^{\circ}$ and $90^{\circ}$ of values $129.5 \%, 2.635 \%, 1.49 \%$ and $1.351 \%$ respectively. Fig. 12c compares the drag and lift coefficient for $\mathrm{C}$ plan shape building.

In place of $\mathrm{L}$ - plan shape building, the drag coefficient is greater than the lift coefficients for wind angles $0^{\circ}, 45^{\circ}$, $90^{\circ}$ and $180^{\circ}$. Peculiarly for the wind angle $135^{\circ} \mathrm{L}$ - plan shape building experience greater lift than drag by $1.07 \%$; it shows that L - plan shape building behaves like a thin body at a moderate angle of attack. $R e$ for L plan shape building at $135^{\circ}$ is $1.13 \times 10^{8}$ which is very low when compared with other wind angles where $R e$ lies between $7.98 \times 10^{7}$ to $8.47 \times 10^{7}$. Fig. $12 \mathrm{~d}$ compares the drag and lift coefficient for $\mathrm{C}$ - plan shape building. In the past research $[20,21]$ investigation is done on drag and lift coefficient on a building with setback and tapering that helps in reducing the mean drag and fluctuating lift force. The lift force is greatly reduced for tapered model of about $40 \%$. Similarly, in the current investigation of different plan shape building a change in drag and lift coefficient values is observed for pentagon, $\mathrm{L}, \mathrm{T}$ and $\mathrm{C}$ plan shape building.
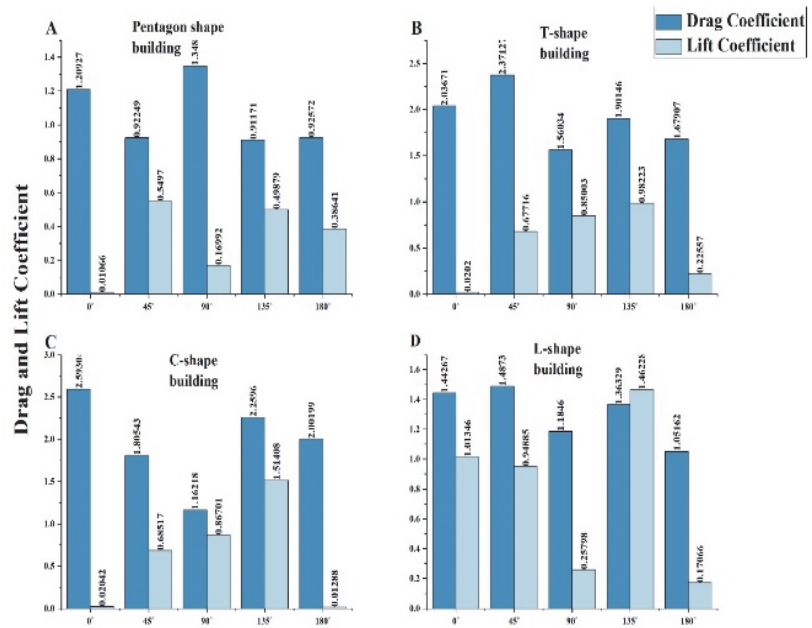

Wind angles in degree

Figure 12 Shows compares drag and lift coefficient for different plan shape building (a) Pentagon (b) T (C) C and (d) L - plan shape 


\subsection{Overturning moment Coefficients}

The mean Over Turning Moment (OTM) along-wind, across-wind and torsional wind coefficients is calculated using theEq. (6), Eq. (7) and Eq. (8):

$$
\begin{aligned}
& \bar{C}_{M D}=\frac{\overline{M_{D}}}{q_{H} B H^{2}} \\
& \bar{C}_{M L}=\frac{\overline{M_{L}}}{q_{H} B H^{2}} \\
& \bar{C}_{M T}=\frac{\overline{M_{T}}}{q_{H} B D H}
\end{aligned}
$$

Here, $\bar{C}_{M D}, \bar{C}_{M L}$ and $\bar{C}_{M T}$ are the mean o.t.m coefficients and $\overline{M_{D}}, \overline{M_{L}}$ and $\overline{M_{T}}$ are the mean overturning moments in along wind, across wind and torsional mode direction. $B$ is the width; $H$ is the model height and $q_{H}$ is the mean velocity pressure at model height. Earlier researcher [24] studied the mean overturning moment coefficient for straight and helical building models and the investigation was carried out with seven different wind angles.

In this paper, the investigation of overturning moment coefficient is done in similar way as done by the previous researcher for the following building shapes such as pentagon, $\mathrm{L}, \mathrm{T}$ and $\mathrm{C}$ plan shape building. The value of mean o.t.m coefficient in along wind direction $\bar{C}_{M D}$ for pentagon, $\mathrm{L}, \mathrm{T}$ and $\mathrm{C}$ plan shape tall building lies between 1 to 1.3 respectively. Fig. 13a shows the variation in mean along wind overturning moment (o.t.m) coefficients for irregular building with varying wind angles. Pentagon plan shape building experiences a maximum moment coefficient at $90^{\circ}$ wind angle followed by $\mathrm{L}$ and $\mathrm{T}$ at $45^{\circ}$ wind angle and $\mathrm{C}$ - plan shape building by $0^{\circ}$ wind angle. Building with different $\mathrm{C}$ - plan shape experiences a maximum moment coefficient of 1.96 followed by $\mathrm{T}, \mathrm{C}$ and Pentagon by $1.90,1.30$ and 1.06 respectively. The along wind moment coefficient values rise and fall as the wind angles increase and minor fluctuation is observed for pentagon, $\mathrm{L}$ and $\mathrm{T}$ plan shape tall buildings and large variation is observed for $\mathrm{C}$ plan shape tall building.

The mean o.t.m coefficient in cross wind direction $\bar{C}_{\mathrm{ML}}$ for pentagon, $\mathrm{L}, \mathrm{T}$ and $\mathrm{C}$ plan shape tall buildings lies between 0.3 to 1.5 respectively. Fig. $13 \mathrm{~b}$ shows the crosswind moment coefficient for different plan shape building with different wind angles. Pentagon plan shape building experiences a maximum lift at $45^{\circ}$ wind angles and other plan shape buildings $\mathrm{L}, \mathrm{T}$ and $\mathrm{C}$ at $135^{\circ}$ wind angle. Maximum lift moment coefficient is found in $\mathrm{L}$ - plan shape building of value 0.77 and followed by other plan shape by $\mathrm{C}, \mathrm{T}$ and Pentagon by $0.61,0.55$ and 0.32 respectively. The cross-wind o.t.m coefficient varies for all the building shapes as the wind angles increase.

The mean o.t.m torsion coefficient $\bar{C}_{M L}$ for pentagon, $\mathrm{L}, \mathrm{T}$ and $\mathrm{C}$ plan shape tall buildings ranges between 1 to 3 respectively. Fig. $13 \mathrm{c}$ shows the twisting moment coefficients for different plan shape building for different wind angles. Pentagon plan shape experiences maximum twisting coefficient at $90^{\circ}$ wind angles, $\mathrm{L}$ and $\mathrm{T}$ at $45^{\circ}$ wind angle and $\mathrm{C}$ plan shape at $0^{\circ}$ wind angle respectively. Maximum twisting occurred at $\mathrm{C}$ plan shape building of value 2.76 , followed by $\mathrm{T}, \mathrm{L}$ and Pentagon by $1.96,1.33$ and 1.07 respectively. Pentagon, $\mathrm{L}$ and $\mathrm{T}$ plan shape buildings experience mild variation in torsional moment coefficient as the wind angle increases. Whereas $\mathrm{C}$ - plan shape building experiences a large variation in torsional coefficient as the wind angle increases.

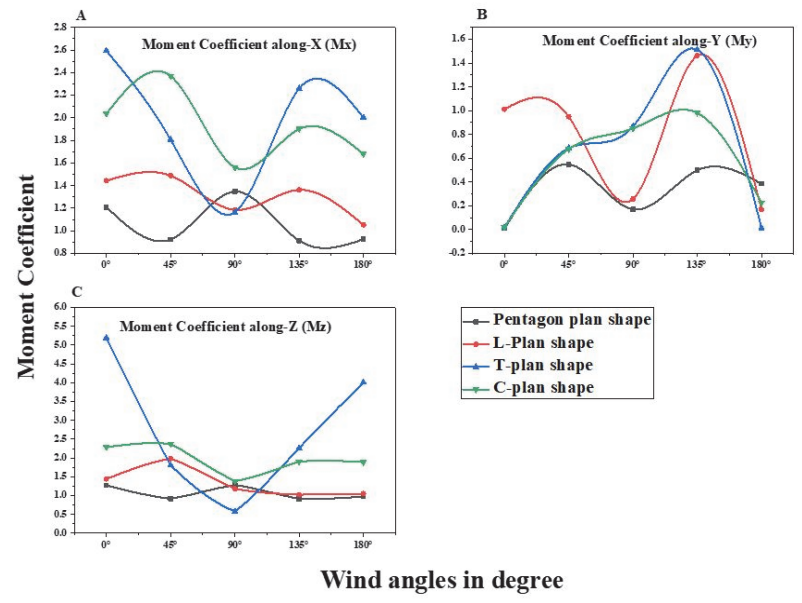

Figure 13 Mean OTM coefficient (a) along-wind (X-direction) (b) Across-wind (Y-direction) (c) Torsional Moment (Z-direction)

\section{CONCLUSION}

Aerodynamic coefficient study is conducted for irregular plan shape buildings such as pentagon, $\mathrm{L}, \mathrm{T}$ and $\mathrm{C}$ plan shapes of same height. The discussion on aerodynamic characteristics of tall buildings directed to the following conclusions:

- The pentagon plan shape building experiences a minimum drag coefficient $\left(C_{d, \min }\right)$ of 1.349 at $90^{\circ}$ wind angle followed by the other building shapes $\mathrm{L}$ and $\mathrm{T}$ with drag coefficients 1.49 and 2.37 at $45^{\circ}$ wind angle and $\mathrm{C}$ plan shape building of 2.57 at $0^{\circ}$ wind angle.

- Minimum lift coefficient $\left(C_{l, \min }\right)$ is experienced at $45^{\circ}$ wind angle by pentagon plan shape building of 0.55 followed by other building shapes such as T, L and C plan that are of $0.98,1.46$ and 1.51 at $135^{\circ}$ wind angles.

- Minimum torsional coefficient is experienced at $90^{\circ}$ wind angle for pentagon plan shape building of value 1.282 followed by $\mathrm{L}$ and $\mathrm{T}$ at $45^{\circ}$ wind angle of value 1.98 and 2.37 respectively and $\mathrm{C}$ plan shape building is 5.19 at $0^{\circ}$ wind angle respectively.

- L - plan shape building experiences a larger lift than drag by $1.07 \%$ at $135^{\circ}$ wind angle and this confirms that cross-wind force is more in this direction when compared to along wind force.

- Pentagon, L, T and C plan shape buildings experience a mean o.t.m coefficient in along wind direction $\bar{C}_{M D}$ which is between 1 to 1.3 , across wind direction $\bar{C}_{\mathrm{ML}}$ between 0.3 to 1.5 and torsion coefficient $\bar{C}_{M T}$ between 1 to 3 respectively.

- Pentagon plan shape building experiences minimum overturning moment coefficients in along-wind, across- 
wind and torsional mode when compared with L, T and C plan shape buildings and this proves that pentagon plan shape building performs better than aerodynamic behavior.

\section{Acknowledgments}

The author would like to thank Department of Civil Engineering in Mepco Schlenk Engineering College, India and Department of Aeronautical Engineering Kumaraguru Engineering College, India, for providing adequate experimental facilities to carry out the research study and sincere thanks to the Institute of Engineers (India) IE(I) for its grateful financial support (Project ID: DR2020004) to complete the project work successfully.

\section{REFERENCES}

[1] Saha, A. K. \& Muralidhar, K. (2000). Experimental study of flow past a square cylinder at high Reynolds numbers. Experiments in fluids, 29, 553-563. https://doi.org/10.1007/s003480000123

[2] Abdollah, B. D., Elham, M. K., Erfan, M. N., \& Payam, B. (2019). Study on wind aerodynamic and flow characteristics of triangular-shaped tall buildings and CFD simulation in order to assess drag coefficient. Ain Shams Engineering Journal,10, 541-548. https://doi.org/10.1016/j.asej.2018.08.008

[3] Aider, J. L. B., Jean, F. W., \& José, E. (2010). Drag and lift reduction of a $3 \mathrm{D}$ bluff-body using active vortex generators. Experiments in Fluids. 48(5), 771-789. https://doi.org/10.1007/s00348-009-0770-y

[4] Baghaei Daemei, A., Khotbehsara, E., Mehrinejad, N., Erfan, M., \& Bahrami, P. (2019). Study on wind aerodynamic and flow characteristics of triangular-shaped tall buildings and CFD simulation in order to assess drag coefficient, Ain Shams Engineering Journal, 10(3), 541-548. https://doi.org/10.1016/j.asej.2018.08.008

[5] Biswarup, B. \& Sujit, K. D. (2020). Experimental and Numerical Study of Wind-Pressure Distribution on Irregular-Plan-Shaped Building. Journal of structural Engineering, 146, 1-14. https://doi.org/10.1061/(ASCE)ST.1943-541X.0002686

[6] Carassale, L., Freda A., \& Marrè-Brunenghi, M. (2014). Experimental investigation on the aerodynamic behavior of square cylinders with rounded corners. Journal of fluids and Structure, 44 (Jan), 195-204. https://doi.org/10.1016/j.jfluidstructs.2013.10.010

[7] Chao, R. \& Yaochun, Z. (2012).Computational Fluid Dynamics study on the performance and mechanism of suction control over a high-rise building. Structure design tall and Special Building, 21, 475-491. https://doi.org/10.1002/tal.622

[8] Chita, G. H. \& Selvi, R. (2017). Effects of upstream terrain characteristics on aerodynamic coefficient of structures. Achives of Civil and Mechanical Engineering, 17, 776-785. https://doi.org/10.1016/j.acme.2017.02.005

[9] Reisenberger, E., Meile, W., Brem, G., \& Muller, W. (2004) Aerodynamic behaviour of prismatic bodies with sharp and rounded edges. Experiments in fluids, 37, 547-558. https://doi.org/10.1007/s00348-004-0840-0

[10] Eswara, K. B., Yukio, T., Akihito, Y. C. K., \& Qingshan, Y. (2013). Experimental investigation on aerodynamic characteristics of various triangular-section high-rise buildings. Journal of Wind Engineering and Industrial Aerodynmics, 122, 60-68. https://doi.org/10.1016/j.jweia.2013.07.002

[11] Flachsbart, O. (1932). 11. Messungen an ebenen und gewölbten Platten. AerodynamischenVersuchsanstaltzu Gottingen, 4, 96-100. https://doi.org/10.1515/9783486764406-017

[12] Gunter, S. (2013). Reynolds-number-effects inflow around a rectangular cylinder with aspectratio 1:5. Journal off luid sand structure, 39, 15-26. https://doi.org/10.1016/j.jfluidstructs.2013.02.013

[13] Sarath, K. H. \& Vijaya, B. R. P. (2017). Pressure measurement studies on a 1:1.5:7 rectangular high rise building model under uniform flow. IOP Conference Series: Material Science Engineering, 225, 012269. https://doi.org/10.1088/1757-899X/225/1/012269

[14] Hai, J. X., Hong, Z. D., Xiao, Y. H., \& Xing, M. (2019). Wind tunnel test on aerodynamic coefficients of multibundled conductors under skew winds, Journal of fluids and structures, 91, 102702. https://doi.org/10.1016/j.jfluidstructs.2019.102702

[15] Hongfu, Z., Dabo, X., \& Jinping, O. (2014). Experimental study of across-wind aerodynamic damping of super highrise buildings with aerodynamically modified square crosssections. 'Structural design of high-rise building, 23, 12251245. https://doi.org/10.1002/tal.1137

[16] Holmes, J. D. (2015), Wind Loading of Structures, Third Edition, CRC Press.

[17] Tang, J. W., Xie, T. M., Felicetti, P.,Tu, J. Y., \& Li, J. D. (2010). Numerical simulations of wind drags of straight and twisted polygonal buildings. Structural design of tall and special building, 22, 62-73. https://doi.org/10.1002/tal.657

[18] Rajasekarababu, K. B., Vinayagamurthy, G., \& Selvi, R. (2019). Experimental and computational investigation of outdoor wind flow around setback building,.Building Simulation, 12, 891-904. https://doi.org/10.1007/s12273-019-0514-8

[19] Kareem, A. (1990). Measurements of pressure and force fields on building models in simulated atmospheric flows. Journal of Wind Engineering and Industrial Aerodynamics, 36, 589-599. https://doi.org/10.1016/0167-6105(90)90341-9

[20] Kim, Y. C. \& Kanda, J. (2013). Wind pressures on tapered and set-back tall buildings. Journal of Fluids and Structures, 39, 306-321. https://doi.org/10.1016/j.jfluidstructs.2013.02.008

[21] Kim, Y. \& Kanda, J. (2010). Characteristics of aerodynamic forces and pressures on square plan buildings with height variations. Journal of Wind Engineering and Industrial Aerodynamics, 98, 449-465. https://doi.org/10.1016/j.jweia.2010.02.004

[22] Lin, N., Letchford, C., Tamura, Y., Liang, B., \& Nakamura, O. (2005). Characteristics of wind forcesacting on tall buildings. Journal of Wind Engineering and Industrial Aerodynamics, 93, 217-242. https://doi.org/10.1016/j.jweia.2004.12.001

[23] Gu, M. \& Quan, Y. (2004). Across-wind loads of typical tall buildings. Journal of Wind Engineering and Industrial Aerodynamics, 92, 1147-1165. https://doi.org/10.1016/j.jweia.2004.06.004

[24] Mohamed E., Khaled, G., \& Ted, S. (2014). Wind load combinations including torsion for rectangular medium-rise buildings. Candian Journal of Civil Engineering, 41, 409420.

[25] Nils, P. V. H., Gunter, S., \& Markus, J. (2017). Experiments on the aerodynamic behaviour of square cylinders with rounded corners at Reynolds numbers up to 12 million. Journal of Fluids and Structures, 74, 214-233. https://doi.org/10.1016/j.jfluidstructs.2017.08.002

[26] Peter, S. (1978). Wind forces in Engineering. $2^{\text {nd }}$ Edition, Pergamon Press.

[27] Ganaga, P. S., Sudharsan, M., Vinodh, K. V., Diwakar, S. V., Sundararajan, T., \& Shaligram. (2014). Effects of aspect ratio and orientation on the wake characteristics of low Reynolds number flow over a triangular prism. Journal of fluid and structures, 46, 59-76. https://doi.org/10.1016/j.jfluidstructs.2013.12.008 
[28] Stefano, G., Lorenzo, R., Gisella, T., \& Alberto Z. (2013). Experimental study of across-wind aerodynamic damping of super high-rise buildings with aerodynamically modified square cross-sections. Structural design of tall and special buildings, 25, 139-157.

[29] Surry, D., \& Djakovich, D. (1995). Fluctuating pressures on models of tall buildings. Journal of Wind Engineering and Industrial Aerodynamics, 58, 81-112. https://doi.org/10.1016/0167-6105(95)00015-J

[30] Tanaka, H., Tamura, Y., Ohtake, K., Nakai, M., \& Kim, Y. C. (2012). Experimental investigation of aerodynamic forces and wind pressures acting on tall buildings with various unconventional configurations. Journal of Wind Engineering and Industrial Aerodynamics, 107-108,179-191. https://doi.org/10.1016/j.jweia.2012.04.014

[31] Türkeli, E. (2014). Determination and Comparison of Wind and Earthquake Responses of Reinforced Concrete Minarets. Arabrian Journal of Science and Engineering, 39, 36653680. https://doi.org/10.1007/s13369-014-0999-5

[32] Wenjuan, L., Mingfeng, H., Hu, J., Guohui, S., \& Chan, C. M. (2010). Experimental and computational simulation for wind effects on the Zhoushantransmission towers. Structural Design of Tall building, 19, 885-900. https://doi.org/10.1002/tal.514

[33] Ze, C., Danesh, K., \& Tafti. (2018). Investigation of drag, lift and torque for fluid flow past a low aspect ratio (1:4) cylinder. Computer and fluids, 177, 123-135. https://doi.org/10.1016/j.compfluid.2018.10.002

\section{Contact information:}

Vigneshwaran RAJENDRAN, Research Scholar

(Corresponding author)

Mepco Schlenk Engineering College, Department of Civil Engineering,

Sivakasi, Tamil Nadu, India

E-mail: vignesh.rajen.93@gmail.com

Prabavathy SHANMUGASUNDARAM, Sr.Professor \& Head

Mepco Schlenk Engineering College, Department of Civil Engineering,

Sivakasi, Tamil Nadu, India

E-mail: spraba@mepcoeng.ac.in 